\title{
HUBUNGAN ANTARA LUAS LAHAN PERTANIAN DENGAN PRODUK DOMESTIK REGIONAL BRUTO SEKTOR PERTANIAN DI KOTA TOMOHON
}

\author{
Aditya Novandy Arotaa \\ Theodora M. Katiandagho \\ Benu Olfie
}

\begin{abstract}
The agricultural sector in the process of production requires a major production factor is land. Tomohon development as an autonomous region led to the need for non-agricultural land is increasing from time to time. This condition causes the competition has taken place in land use. Feared an increased need for non-agricultural land will lead to land conversion of agricultural land to non-agricultural. The transfer of land use will have an impact on agricultural production that will affect the agricultural sector GDP. This study aims to determine the relationship between the area of agricultural land with a regional gross domestic product of agriculture in Tomohon. This study was conducted over four months starting in February 2015 to May 2015 in Tomohon. The data are used, in this study, is a secondary data obtained from the Office of National Statistics Agency (BPS) and the Department of Agriculture in To-mohon. Data presented tabularize and and analyzed using correlation analysis. The results showed that, in the last three years, agricultural land area in Tomohon shrinkage due to the need for non-agricultural land, especially residential construction increased. It is given Tomohon is a city that is building. Reduction of agricultural land in 2012 amounted to 1.77 percent by the year 2014 decreased by 0, 01 percent. Instead rate of growth of gross regional domestic product of the year 2012 increased by 6.54 percent to 6.92 percent in 2014. The study concluded that the impact of agricultural land being against the gross regional domestic product, caused by another factor, namely the constant price factors that influence regional gross do-mestic product of Tomohon. Thereforet, when the land area or size increased in 2005-2011 and decreased in the year 2012 - 2014 however regional gross domestic product still increased. The relationship between land area with a regional gross domestic product is being categorized correlated with the value of the correlation is $0.62 .{ }^{*}$ er*
\end{abstract}

Keywords: Luas Lahan Pertanian, Produk Domestik Regional Bruto, Pertanian, Tomohon

\section{ABSTRAK}

Sektor pertanian dalam proses produksinya membutuhkan faktor produksi utama yaitu lahan. Perkembangan Kota Tomohon sebagai daerah otonom menyebabkan kebutuhan akan lahan untuk non-pertanian terus meningkat dari waktu ke waktu. Kondisi ini menyebabkan telah terjadi persaingan dalam penggunaan lahan. Dikawatirkan peningkatan kebutuhan lahan non-pertanian akan menyebabkan pengalihan fungsi lahan dari lahan pertanian ke nonpertanian. Pengalihan fungsi lahan ini akan berdampak pada produksi pertanian yang akan mempengaruhi PDRB sektor pertanian. Penelitian ini bertujuan untuk mengetahui hubungan antara luas lahan pertanian dengan produk domestik regional bruto sektor pertanian di Kota Tomohon. Penelitian ini dilakukan selama empat bulan mulai pada bulan Februari 2015 hingga Mei 2015 di Kota Tomohon. Data yang digunakan, pada penelitian ini, adalah data sekunder yang diperoleh dari Kantor Badan Pusat Statistik (BPS) dan Dinas Pertanian di Kota Tomohon. Data disajikan secara tabellaris dan dianalisis dengan menggunakan analisis korelasi. Dari hasil penelitian menunjukkan bahwa, dalam tiga tahun terakhir, luas lahan pertanian di Kota Tomohon mengalami penyusutan diakibatkan kebutuhan akan lahan untuk non-pertanian, terutama pembangunan pemukiman meningkat. Hal ini mengingat Kota Tomohon adalah Kota yang sedang membangun. Pengurangan luas lahan pertanian pada tahun 2012 sebesar 1,77 persen mengalami penurunan hingga tahun 2014 sebesar 0,01 persen. Sebaliknya laju pertumbuhan produk domestik regional bruto mengalami peningkatan dari tahun 2012 sebesar 6,54 persen menjadi 6,92 persen pada tahun 2014. Hasil penelitian menyimpulkan bahwa luas lahan pertanian berpengaruh sedang terhadap produk domestik regional bruto, disebabkan adanya faktor lain yaitu faktor harga konstan yang turut mempengaruhi produk domestik regional bruto dari Kota Tomohon. Sehingga ketika luas lahan meningkat pada tahun 2005-2011 dan menurun pada tahun 2012 - 2014 produk domestik regional bruto sektor pertanian terus meningkat. Hubungan antara luas lahan dengan produk domestik regional bruto dikategorikan berkorelasi sedang dengan nilai korelasinya 0,62 .

Kata Kunci: Luas Lahan Pertanian, Produk Domestik Regional Bruto, Pertanian, Tomohon 


\section{PENDAHULUAN}

\section{Latar Belakang}

Kota Tomohon adalah kota pemekaran wilayah minahasa sejak tahun 2003. Perekonomian Kota Tomohon berkembang cukup baik hal ini dapat di lihat dari pertumbuhan PDRB yang meningkat setiap tahunnya dapat di lihat pada Tabel 1. Kota Tomohon dikenal sebagia pusat produksi sayuran, tanaman hias, dan bunga potong, sehinga Kota Tomohon di kenal juga sebagai kota bunga. Tomohon sebagai salah satu pemasok sayur dan bunga potong bagi wilayah manado dan sekitarnya, sehingga sektor pertanian merupakan penyumbang terbesar pada PDRB Tomohon.

Tabel 1. Produk Domestik Regional Bruto Kota Tomohon

\begin{tabular}{cccc}
\hline Tahun & $\begin{array}{c}\text { PDRB } \\
\text { Kota } \\
\text { Tomohon }\end{array}$ & $\begin{array}{c}\text { Pertumbuhan } \\
(\boldsymbol{\%})\end{array}$ & $\begin{array}{c}\text { Persentase } \\
(\boldsymbol{\%})\end{array}$ \\
\hline 2005 & $397.845,76$ & & \\
2006 & $513.214,04$ & 28,99 & 6,20 \\
2007 & $541.042,55$ & 5,42 & 8,44 \\
2008 & $589.501,65$ & 8,95 & 9.19 \\
2009 & $625.401,93$ & 6,08 & 9,75 \\
2010 & $663.557,62$ & 6,10 & 10,35 \\
2011 & $706.974,18$ & 6,54 & 11,02 \\
2012 & $755.929,86$ & 6,92 & 11,79 \\
2013 & $808.306,70$ & 6,92 & 12,60 \\
2014 & $808.306,70$ & 0,00 & 12,60 \\
\hline
\end{tabular}

Sumber : BPS Kota Tomohon

Sektor pertanian dalam proses produksinya membutuhkan faktor produksi utama yaitu lahan. Perkembangan Kota Tomohon sebagai daerah otonom menyebabkan kebutuhan akan lahan untuk non-pertanian terus meningkat dari waktu ke waktu. Kondisi ini menyebabkan telah terjadi persaingan dalam penggunaan lahan. Dikawatirkan peningkatan kebutuhan lahan non- pertanian akan menyebabkan pengalihan fungsi lahan dari lahan pertanian ke non pertnian.

Pengalihan fungsi lahan ini akan berdampak pada produksi pertanian yang akan mempengaruhi PDRB sektor pertanian.

Untuk melihat apakah pergeseran luas lahan pertanian mempengaruhi PDRB sektor pertanian dilakukanlah penelitian ini.
Konsep Lahan
Lahan (land) merupakan suatu wilayah di permukaan bumi, mencakup semua komponen biosfer yang dapat dianggap tetap atau bersifat siklis yang berada di atas dan dibawah wilayah tersebut, termasuk atmosfer, tanah, batuan induk, relief, hidrologi, tumbuhan dan hewan, serta segala akibat yang ditimbulkan oleh aktivitas manusia dimasa lalu dan sekarang; yang kesemuanya itu berpengaruh terhadap penggunaan lahan oleh manusia pada saat sekarang dan di masa akan datang (Brinkman dan Smyth, 1973; Vink, 1975; dan FAO, 1976, dalam Juhadi 2007).

Lahan mempunyai peranan sangat penting bagi kehidupan manusia, Segala macam bentuk intervensi manusia secara siklis dan permanen untuk memenuhi kebutuhan hidupnya, baik yang bersifat material maupun spiritual yang berasal dari lahan tercakup dalam pengertian pemanfaatan lahan. Berbagai tipe pemanfaatan lahan dijumpai di permukaan bumi, masing-masing tipe mempunyai karakteristik tersendiri. (Juhadi, 2007)

Lahan dalam arti ruang menurut (Sadyohutomo 2008) memiliki keunikan sebagai berikut:

a. Dari aspek lokasi, letaknya tetap, tidak dapat dipindah.

b. Luas lahan pada suatu wilayah hampir tidak berubah. Perubahan dapat terjadi apabila ada reklamasi perairan menjadi dataran.

c. Peranan lahan bagi kehidupan manusia berdimensi kompleks, yaitu ekonomi, sosial, budaya, politik serta pertahanan dan keamanan.

Menurut (Sumardjono 2008), lahan mempunyai ciri khusus yang bersegi dua, yakni sebagai benda dan sebagai sumberdaya alam. Lahan menjadi benda bila telah diusahakan oleh manusia, misalnya menjadi tanah pertanian atau dapat pula dikembangkan menjadi tanah perkotaan. Pengembangannya dilakukan oleh pemerintah melalui penyediaan prasarana. Penyediaan prasarana ini membawa akibat pada peningkatan nilai lahan. Ciri lain dari lahan adalah sifatnya yang tetap, jumlahnya yang terbatas, serta penyediaannya yang tidak dapat diubah. 
Menurut topografi, lahan dibedakan kemiringannya menjadi empat, antara lain (Hanafie R, 2010) :

1. Lahan dengan lereng $0-3 \%$ : datar, termasuk rawa-rawa, untuk tanaman padi atau perkebunan kelapa.

2. Lahan dengan lereng 3-8\% : baik untuk tanaman setahun tertentu apabila dibuat teras atau kontur.

3. Lahan dengan lereng 8-15\% : baik untuk tanaman rumput sehingga cocok untuk area peternakan.

4. Lahan dengan lereng $>15 \%$ : baik untuk tanaman kayu sehingga cocok dijadikan area perkebunan atau kehutanan.

Secara mikro, pengaruh tanah dalam pertanian dilihat dari penguasaan lahan, luas lahan garapan, dan nilai lahan.

Macam-macam lahan menurut kepemilikan oleh petani dibedakan menjadi (Hanafie R, 2010) :

1. Lahan yang dibeli, baik kontan maupun angsuran.

2. Lahan warisan, yaitu lahan yang diterima oleh ahli waris berdasarkan pembagian dari harta orangtua yang telah meninggal dunia.

3. Lahan yang diperoleh secara hibah, yaitu lahan yang diterima/didapat secara CumaCuma dari badan/harta orang yang masih hidup.

4. Lahan yang dimiliki berdasarkan land reform, permohonan biasa, bagian lahan transmigrasi, pembagian lahan dari pembukaan hutan, hukum adat, atau menyerahan dari program perkebunan inti rakyat.

5. Lahan sewa, yaitu lahan yang didapat dengan perjanjian sewa, yang besarnya sewa sudah ditentukan telebih dahulu tanpa melihat besar kecilnya hasil produksi.

6. Lahan bagi hasil (sakap), yaitu lahan sewa,tetapi dengan perjanjian besarnya sewa berdasarkan hasil panen / produksi dan dibayarkan setelah panen.

7. Lahan gadai, yaitu lahan yang berasal dari pihak lain sebagai jaminan pinjaman uang pihak yang menggadaikan lahannya.

8. Lahan bengkok / pelungguh, yaitu lahan milik desa/kelurahan yang dikuasakan kepada pamong desa atau bekas pamong desa sebagai gaji atau pensiun.
9. Lahan bebas sewa, serobotan, dan lahan garapan. Lahan bebas sewa adalah lahan yang didapatkan dengan tanpa membeli atau membayar sewa dan bukan merupakan lahan milik, tetapi hanya diizinkan memakai dengan bebas sewa.

10. Lahan yang dikuasai adalah lahan milik sendiri ditambah lahan yang berasal dari pihak lain dan dikurangi lahan yang berada dipihak lain. Lahan tersebut berupa lahan sawah dan lahan bukan sawah.

11. Lahan pertanian adalah lahan yang dikuasai dan pernah diusahakan untuk pertanian selama setahun yang lalu. Lahan tersebut mencangkup lahan sawah, huma, ladang, tegal/kebun, lahan perkebunan, hutan, dan lahan untuk pengembalaan/padang rumput.

12. Lahan sawah adalah lahan pertanian yang berpetak-petak dan dibatasi oleh pematang (galengan), saluran untuk menahan/ menyalurkan air yang biasanya ditanami padi sawah tanpa memandang dari mana diperolehnya atau status lahan tersebut.

13. Lahan bukan sawah adalah semua lahan selain lahan sawah yang biasanya ditanami dengan tanaman musiman atau tanaman tahunan, lahan untuk kolam atau untuk kegiatan usaha pertanian lainnya. Lahan bukan sawah meliputi huma, ladang, tegal, kebun, kolam/tebat/empang, dan lahan perkebunan.

14. Huma adalah lahan kering yang biasanya ditanami tanaman musiman dan penggunaannya hanya semusim atau dua musim, kemudian ditinggalkan bila sudah tidak subur lagi. Kemungkinan lahan ini beberapa tahun kemudian akan dikerjakan kembali bila kesuburannya kembali.

15. Ladang/tegal/kebun adalah lahan kering yang ditanami tanaman musiman atau tanaman tahunan, serta terpisah dengan halaman sekitar rumah dan penggunaanya tidak berpindah-pindah. Lahan yang dibiarkan kosong kurang dari 1 tahun (menunggu masa penanaman yang akan datang) dianggap sebagai kebun/tegal apabila hendak ditanami tanaman musiman/tahunan atau dianggap sebagai lahan perkebunan apabila akan ditanami tanaman perkebunan. 
16. Lahan tidur adalah lahan yang biasanya digunakan untuk usaha pertanian, tetapi tidak dimanfaatkan lebih dari 2 tahun.

Setiap jenis penggunaan lahan (pertanian maupun non pertanian) memiliki nilai land rent yang berbeda. Jenis penggunaan lahan dengan keuntungan komparatif tertinggi akan mempunyai kapasitas penggunaan lahan terbesar, sehingga penggunaan lahan tertentu akan dialokasikan untuk kegiatan yang memberikan nilai land rent tertinggi. Demikian juga dengan penggunaan lahan pertanian meskipun lebih lestari kemampuannya dalam menjamin kehidupan petani, tetapi hanya dapat memberikan sedikit keuntungan materi atau finansial dibandingkan sektor industri, pemukiman dan jasa lainnya, sehingga konversi lahan pertanian ke penggunaan lainya tidak dapat dicegah.

\section{Fungsi Lahan}

Menurut Manuwoto (1991) fungsi lahan secara umum dapat dibagi 2 yaitu lahan berfungsi untuk kegiatan budidaya dan lindung:

a. Lahan yang mempunyai fungsi lindung ternyata sebagai atau seluruhnya telah lama di huni oleh penduduk, Berbagai kegiatan sosial ekonomi telah dilaksanakan secara turun-temurun dan telah tertanam secara kuat nilai-nilai sosial budaya yang berkaitan dengan yang ditempatinya.

b. lahan yang mempunyai fungsi lindung yang telah ditetapkan sebagai atau seluruhnya telah terlanjur diserahkan kepada pengusaha, seperti HPH dalam jangka waktu tertentu.

c. lahan budidaya potensial yang telah ditetapkan untuk pengembangan produksi pertanian, ternyata banyak yang belum dapat dijangkau atau terisolir, tidak berpenduduk atau penduduknya sangat jarang.

d. adanya benturan kepentingan antara berbagai faktor tertentu seperti misalnya lahan budidaya yang telah diperuntukan bagi suatu sektor tertentu yang potensial (pengairan atau pertambangan) ternyata telah dihuni oleh penduduk dengan kegiatan pertanian yang telah dilakukan secara turun temurun.

\section{Alih Fungsi Lahan}

Alih fungsi lahan adalah sebuah mekanisme yang mempertemukan permintaan dan penawaran terhadap lahan dan menghasilkan kelembagaan lahan baru dengan karakteristik sistem produksi yang berbeda. Fenomena alih fungsi lahan adalah bagian dari perjalanan transformasi struktur ekonomi nasional. Pertumbuhan ekonomi dan penduduk yang memusat diwilayah perkotaan menuntut ruang lebih luas ke arah luar kota bagi berbagai aktivitas ekonomi dan untuk pemukiman. Sebagai akibatnya, wilayah hinterland yang sebagian besar berupa lahan pertanian sawah, beralih fungsi (konversi) menjadi lahan nonpertanian dengan tingkat peralihan yang beragam antar periode dan wilayah.

Dalam garis besarnya alih fungsi lahan dapat berjalan secara sistematis dan sporadis. Peralihan secara sistematis memuat karakter perencanaan dan keinginan publik sehingga luasan lahan hasil peralihan lebih terkendali dan terkonsolidasi dalam kerangka perencanaan tata ruang. Pertemuan permintaan dan penawaran dialokasikan dan diputuskan didalam suatu kelembagaan dengan tujuan memberi kepuasan kepada pembeli dan penjual atau stakeholder lainnya serta mengoptimalkan tujuan penggunaan lahan. Mekanisme ini terlihat dalam pembangunan kawasan industri, pemukiman dan sarana infrastrukturnya. Peralihan secara sporadis memuat karakter lebih individual atau oleh sekelompok masyarakat sehingga luasan hasil peralihan tidak dapat diprediksi dan menyebar tidak terkonsolidasi. Pertemuan antara permintaan dan penawaran diputuskan diluar kelembagaan sehingga sering mengakibatkan kerugian disalah satu pihak dan disertai penggunaan lahan yang tidak optimal (Nugroho, dan Dahuri, 2012).

Alih fugsi lahan terjadi di wilayah perkotaan (urban) maupun perdesaan (rural). Ruang-ruang terbuka berupa lahan hijau dan produktif saat ini terus mengalami penyusutan akibat pembangunan kota (urban spraw) untuk permukiman, industri, komersil, dan peruntukan lainnya. Di wilayah perkotaan, alih fungsi lahan telah menjadi permasalahan sosial, karena banyak lahan/ruang publik hijau di konversi menjadi ruang komersil (Baja, 2014). 


\section{Sektor Pertanian}

Sektor pertanian telah berperan dalam perekonomian nasional melalui pembentukan PDRB, perolehan devisa, penyediaan pangan, dan bahan industri, pengetasan kemiskinan, menciptakan lapangan kerja, dan meningkatkan pendapatan masyarakat. Sektor pertanian mampunyai efek pengganda kedepan yang besar melalui keterkaitan input-output outcom antara industri, konsumsi, dan investasi. Hal ini terjadi nasional dan regional karena keunggulan komparatif sebagian besar wilayah indonesia adalah sektor pertanian (Laoh, 2008).

Suhendara (2004) mengatakan bahwa sektor pertanian yang berhasil merupakan persyaratan bagi pembangunan sektor industri dan jasa. Para perancang pembangunan indonesia pada awalnya masa pemerintahan orde baru menyadari benar hal tersebut, sehingga pembangunan jangka panjang dirancang secara bertahap. Pada tahap pertama, pembangunan dititik beratkan pada pembangunan sektor pertanian dan industri penghasil sarana produksi pertanian. Pada tahap kedua, pembangunan dititik beratkan pada industri pengolahan penunjang pertanian (agroindustri) yang berkelanjutan secara bertahap dialihkan pada pembangunan industri mesin dan logam.

Menurut Sutrisno (2000) sektor pertanian mampu menjadi tumpuan hidup masyarakat yang sedang menghadapi krisis ekonomi, tetapi menjadi sektor utama dalam proses pembangunan bukanlah suatu hal yang mudah tetapi dibutuhkan investasi yang mahal dan akan menghadapi tantangan yang berasal dari perubahan-perubahan yang terjadi.

Sektor pertanian selama ini telah memberikan sumbangan yang tidak sedikit dalam proses pembangunan. Namun akhir-akhir ini, produktivitas sektor pertanian cenderung terus menurun sehubungan dengan timbulnya berbagai permasalahan dari kegiatan pembangunan yang hanya berorientasikan pada pertumbuhan ekonomi semata. Beberapa tantangan yang menghadang sektor pertanian pada saat ini dan pada masa-masa yang akan datang diantaranya sebagai berikut :

1. Cepatnya laju alih fungsi lahan pertanian produktif menjadi berbagai peruntukan lainnya, seperti misalnya pertumbuhan industri dan sektor-sektor pembangunan lainnya, serta kebutuhan perumahan dan pemukiman akibat meningkatnya jumlah penduduk.

2. Derasnya mobilisasi penduduk ke perkotaan yang diantaranya diakibatkan oleh semakin rendahnya tingkat pendapatan masyarakat pedesaan karena makin sempitnya lahan usaha. Umumnya, mereka kemudian bekerja diluar sektor pertanian.

\section{Faktor-Faktor Produksi Pertanian}

Faktor-faktor produksi pertanian terdiri dari: Tanah, Tenaga kerja, Modal.

Faktor produksi alam dan tenaga kerja sering disebut sebagai faktor produksi primer, faktor produksi modal disebut faktor produksi sekunder.

Produksi fisik dihasilkan oleh bekerjanya beberapa faktor produksi sekaligus, yaitu tanah, modal dan tenaga kerja. Untuk menggambarkan dan/atau menganalisis peranan masing-masing faktor produksi terhadap produksi fisik, dari sejumlah faktor produksi yang digunakan, salah satu faktor produksi dianggap sebagai variabel (berubah-ubah), sementara faktor produksi lainnya diasumsikan konstan (tidak berubah). Hubungan fungsional berlaku untuk semua faktor produksi, yaitu tanah, modal, dan tenaga kerja, termasuk faktor produksi keempat, yaitu manajemen yang berfungsi mengkoordinir ketiga faktor produksi yang lain. Pembagian faktor produksi secara konvesional adalah sebagai berikut :

1. Tanah. Sumbangannya dalam bentuk unsurunsur tanah yang asli dan sifat-sifat tanah yang tak dapat dirusakan (original and indestructible properties of the soil) dimana hasil pertanian dapat diperoleh.

2. Tenaga kerja petani (labor), yaitu suatu alat kekuasaan fisik dan otak manusia yang tidak dapat dipisahkan dari manusia dan ditunjukan kepada usaha produksi. Tenaga kerja yang bukan bertujuan usaha produksi misalnya tenaga untuk sport disebut langka bebas. Bila seorang petani mempunyai ternak sapi yang digunakan membajak sawah, atau suatu perkebunan yang mempunyai traktor untuk mengelola tanah, apakah sapi dan traktor itu termasuk faktor produksi tenaga kerja? Sapi dan traktor itu 
bukan faktor tenaga kerja, tetapi masuk dalam faktor produksi modal. Faktor produksi tenaga kerja tidak dapat dipisahkan dari manusia, sapi dan traktor jelas berpisah dengan manusia. Sapi dan traktor dapat menggantikan tenaga kerja manusia dalam hal membajak dan mengelolah tanah.

3. Modal, yaitu sumber-sumber ekonomi diluar tenaga kerja yang dibuat oleh manusia. Dalam pengertian luas dan umum, merupakan keseluruhan nilai dari sumbersumber ekonomi nonmanusiawi, termasuk tanah. Inilah sebabnya seringkali petani menyebutkan bahwa modal satu-satunya yang mereka miliki adalah tanah. Ini cukup beralasan karena bagaimanapun juga petani telah memasukan berbagai unsur modal ke dalam tanah (misalnya, air dan pupuk) untuk mendukung tingkat kesuburannya (Hanafie, 2010).

\section{Pengertian Produk Domestik Regional Bruto (PDRB)}

Informasi hasil pembangunan yang didapatkan dapat dimanfaatkan dalam penentuan kebijakan pembangunan suatu wilayah. PDRB merupakan ukuran keberhasilan pembangunan suatu wilayah, khususnya dibidang ekonomi salah satu alat yang dapat digunakan sebagai indikator pertumbuhan ekonomi di suatu wilayah.

Pendapatan regional didefinisikan
sebagai tingkat (besarnya) masyarakat pada wilayah, dimana tingkat pendapatan regional dapat diukur dari total pendapatan wilayah ataupun pendapatan ratarata masyarakat pada daerah tersebut (Tarigan, 2007).

Produk Domestik Regional Bruto adalah jumlah nilai tambah bruto (gross value added) yang timbul dari seluruh sektor perekonomian di suatu wilayah dalam kurun waktu tertentu biasanya satu tahun ataupun dalam tiga bulan atau semesteran. Sedangkan, nilai tambah adalah nilai produksi (output) dikurangi dengan biaya antara (intermediate cost). Nilai tambah bruto mencakup komponenkomponen faktor pendapatan (upah dan gaji, bunga, sewa, dan keuntungan), penyusutan dan pajak tidak langsung neto. Jadi dengan menghitung nlai tambah bruto dari masingmasing sektor dan menjumlahkan nilai tambah bruto dari seluruh sektor tadi, akan menghasilkan Produk Domestik Regional Bruto atas dasar harga pasar (Sjafrizal, 2015).

Manfaat dari data PDRB adalah sebagai berikut (BPS, 2014) :

1) Mengetahui atau menelaah struktur ataususunan perekonomian suatu wilayah.

2) Membandingkan perekonomian suatu wilayah dari waktu ke waktu.

3) Membandingkan perekonomian antar wilayah.

4) Merumuskan kebijaksanaan pemerintah.

PDRB secara berkala dapat disajikan dalam dua bentuk yaitu atas dasar harga berlaku dan atas dasar harga konstan pada suatu tahun dasar maupun triwulan, sebagai berikut dijelaskan (BPS, 2014):

1. Penyajian atas dasar harga berlaku, semua agregat pendapatan dinilai atas harga yang berlaku pada masing-masing tahun, baik pada saat menilai produksi dan biaya antara maupun pada penilaian komponen nilai tambah dan komponen pengeluaran PDRB.

2. Penyajian atas dasar harga konstan pada suatu tahun dasar, semua agregat pendapatan dinilai atas harga yang terjadi pada tahun dasar (dalam hal ini dipakai harga konstan didasarkan harga pada tahun 2000). Karena menggunakan harga tetap, maka perkembangan agregat dari tahun ke tahun semata-mata disebabkan oleh perkembangan riil dari kuantum produksi tanpa mengandung fluktuasi harga.

Dalam perhitungan PDRB atas dasar harga berlaku ada dua metode yaitu metode langsung dan metode tidak langsung.Metode langsung adalah perhitungan dengan menggunakan data daerah atau data asli yang menggambarkan kondisi daerah dan digali dari sumber data yang ada di daerah itu sendiri. Hal ini berbeda dengan metode tidak langsung adalah perhitungan dengan mengalokasikan pendapatan nasional menjadi pendapatan regional memakai berbagai macam indikator, 
antara lain jumlah produksi, jumlah penduduk, luas areal sebagai alokatornya (Tarigan, 2007).

Metode langsung dapat dilakukan dengan menggunakan tiga macam pendekatan (Tarigan, 2007), yaitu:

\section{a. Pendekatan Produksi}

Pendekatan produksi adalah penghitungan nilai tambah barang dan jasa yang diprediksi oleh suatu kegiatan/sektor ekonomi dengan cara mengurangkan biaya antara dari total nilai produksi bruto sektor atau subsektor tersebut. Pendekatan ini banyak digunakan untuk memperkirakan nilai tambah dari sektor/kegiatan yang produksinya berbentuk fisik/barang, misalnya pertanian, industri dan sebagainya. Nilai tambah merupakan selisih antara nilai produksi (output) dan nilai biaya antara (intermediate cost), yaitu bahan baku dari luar yang dipakai dalam proses produksi.

b. Pendekatan Pendapatan

Dalam pendekatan pendapatan, nilai tambah dari setiap kegiatan ekonomi diperkirakan dengan menjumlahkan semua balas jasa yang diterima faktor produksi, yaitu upah dan gaji dan surplus usaha, penyusutan, dan pajak tidak langsung neto.

c. Pendekatan Pengeluaran

Pendekatan dari segi pengeluaran bertitik tolak pada penggunaan akhir dari barang dan jasa di dalam wilayah kabupaten/kota. Jadi produk domestik regional dihitung dengan cara menghitung berbagai komponen pengeluaran akhir yang membentuk produk domestik regional tersebut. Secara umum pendekatan pengeluaran dapat dilakukan dengan berbagai cara sebagai berikut :

a. Melalui pendekatan penawaran yang terdiri dari metode arus barang, metode penjualan eceran dan metode penilaian eceran.

b. Melalui pendekatan permintaan yang terdiri dari pendekatan survei pendapatan pengeluaran rumah tangga metode data anggaran belanja, metode balance sheet dan metode statistik perdagangan luar negeri.

Sedangkan metode tidak langsung (Metode Alokasi) adalah metode penghitungan dengan cara alokasi dengan memakai berbagai macam indikator produksi atau indikator lainnya yang cocok sebagai alokator. Alokator yang dapat digunakan dapat didasarkan atas : a. Nilai produksi bruto atau netto

b. Jumlah produsi fisik

c. Tenaga kerja

d. Penduduk, dan

e. Alokator lainnya yang dianggap cocok untuk daerah yang bersangkutan.

\section{Analisis Korelasi}

Analisis korelasi merupakan salah satu teknik statistik yang digunakan untuk menganalisis hubungan antara dua variabel atau lebih yang bersifat kuantitatif. Misalnya, bila $X$ menyatakan besarnya biaya iklan dan $\mathrm{Y}$ besarnya penjualan tahunan total, maka mungkin akan timbul pertanyaan dalam diri kita apakah penurunan biaya iklan juga kemungkinan besar diikuti dengan penurunan nilai penjualan tahunan. Dalam kasus lain, bila $X$ adalah umur suatu mobil bekas dan Y nilai jual mobil tersebut, maka kita membayangkan nilai-nilai $X$ yang besar berpadanan dengan nilai-nilai $\mathrm{Y}$ yang kecil, dan sebaliknya nilai-nilai $X$ yang kecil berpadanan dengan nilai-nilai $\mathrm{Y}$ yang besar Analisis Korelasi mencoba mengukur kekuatan hubungan antara dua peubah demikian melalui sebuah bilangan yang disebut Koefisien Korelasi.

Kita mendefinisikan Koefisien Korelasi Linier sebagai ukuran hubungan linear antara dua peubah acak $\mathrm{X}$ dan $\mathrm{Y}$, dan dilambangkan dengan r. Jadi, $r$ mengukur sejauh mana titiktitik menggerombol sekitar sebuah garis lurus. Perlu diingatkan bahwa koefisien korelasi antara dua peubah adalah suatu ukuran hubungan linear antara kedua peubah tersebut, sehingga nilai $r=0$ berimplikasi tidak adanya hubungan linear, bukan bahwa antara kedua peubah itu pasti tidak terdapat hubungan. Kita masih akan memperoleh korelasi nol meskipun jelas ada hubungan taklinear yang kuat antara kedua peubah itu.

Ukuran korelasi linear antara dua peubah yang paling banyak digunakan adalah yang disebut koefisien korelasi momen-hasilkali pearson atau ringkasannya koefisien korelasi contoh.

\section{Rumusan Masalah}

Berdasarkan latar belakang, maka yang menjadi permasalahan dalam penelitian ini adalah: Bagaimana Hubungan antara Luas lahan pertanian dengan Produk Domestik Regional Bruto sektor pertanian di Kota Tomohon. 


\section{Tujuan}

Adapun yang menjadi tujuan penelitian ini adalah untuk menganalisis hubungan antara Luas Lahan Pertanian dengan Produk Domestik Regional Bruto Sektor Pertanian Kota Tomohon.

\section{Manfaat Penulisan}

Hasil penulisan ini diharapkan dapat bermanfaat dan menjadi sumbangan ilmu pengetahuan serta informasi tentang pengunaan lahan pertanian di Kota Tomohon.

\section{METODOLOGI PENELITIAN}

\section{Waktu Dan Tempat Penelitian}

Penelitian ini telah dilakasanakan mulai dari Bulan Februari 2015 sampai Bulan Mei 2015 di Kota Tomohon.

\section{Metode Pengumpulan Data}

Data yang digunakan dalam penelitian ini adalah data sekunder yang diperoleh dari Badan Pusat Statistik (BPS), Badan Pertanahan Nasional (BPN), dan Dinas Pertanian.

\section{Konsep Pengukuran Variabel}

Secara keseluruhan, variabel-variabel yang diamati dalam penelitian ini adalah sebagai berikut :

1. Luas Lahan Pertanian di Kota Tomohon sepuluh tahun terakhir 2005-2014.

2. Produk Domestik Regional Bruto (PDRB) Sektor Pertanian Kota Tomohon sepuluh tahun terakhir 2005-2014.

3. Luas Panen di Kota Tomohon sepuluh tahun terakhir 2005-2014.

\section{Analisis Data}

Untuk mengetahui penggunaan Lahan Pertanian di Kota Tomohon Metode analisis data yang digunakan adalah Data disajikan dalam bentuk tabel dan di analisis dengan analisis deskritif dan analisis Korelasi.

\section{HASIL DAN PEMBAHASAN}

\section{Deskripsi Lokasi Penelitian}

\section{Gambaran Umum Wilayah Penelitian}

Kota Tomohon terletak di $23 \mathrm{Km}$ selatan Kota Manado Provinsi Sulawesi Utara, berada pada ketinggian 750-800 M diatas permukaan laut dan memiliki topografi perbukitan datar. Kota Tomohon berada pada $01^{\circ} 15^{\prime}$ Lintang Utara dan $124^{\circ} 50^{\prime}$ Bujur Timur. Kota Tomohon terdiri atas 5 kecamatan, dimana kecamatan terluas adalah kecamatan Tomohon Utara $\left(42,28 \mathrm{Km}^{2}\right)$ dan kecamatan Tomohon Tengah sebagai kecamatan terkecil $\left(9,41 \mathrm{Km}^{2}\right)$. Luas wilayah Kota Tomohon berdasarkan UU No. 10 Tahun 2013 sekitar 147,21 Km² dengan jumlah penduduk mencapai 95.157 jiwa. Adapun batas-batas wilayah Kota Tomohon sebagai berikut :

Sebelah Utara: Kecamatan Pineleng,

Kabupaten Minahasa

Sebelah Selatan: Kecamatan Sonder

Kabupaten Minahasa

Sebelah Barat: Kecamatan Tombariri,

Kabupaten Minahasa

Sebelah Timur: Kecamatan Tondano Utara, Kabupaten Minahasa

\section{Keadaan Iklim}

Keadaan iklim Kota Tomohon pada umumnya sama dengan daerah-daerah lain di Indonesia. Berdasarkan peta iklim Oldemen tipe iklim untuk lokasi Kota Tomohon termasuk tipe iklim D1. Pada bulan April dan November terjadi curah hujan yang tinggi sedangkan curah hujan terendah terjadi pada bulan Agustus. Kota yang di juluki kota bunga ini, memiliki temperatur udara rata-rata tahunan $22,83^{\circ} \mathrm{C}$ dengan temperatur minimum $18,9^{\circ} \mathrm{C}$ dan temperatur maksimum mencapai $28,3^{\circ} \mathrm{C}$.

\section{Kepadatan Penduduk}

Berdasarkan data yang dikumpulkan oleh BPS Kota Tomohon, penduduk Kota Tomohon berjumlah 95.157 jiwa. Dengan luas wilayah 147,21 $\mathrm{Km}^{2}$ maka kepadatan penduduk di Kota Tomohon mencapai 646 jiwa $/ \mathrm{Km}^{2}$. 
Tabel 2. Statistik Kependudukan Kota Tomohon Tahun 2014

\begin{tabular}{cc}
\hline Uraian & $\mathbf{2 0 1 4}$ \\
\hline Jumlah Penduduk (000) & 98,686 \\
jiwa & \\
Kepadatan Penduduk & 670,38 \\
(jiwa/ $\left./ \mathrm{Km}^{2}\right)$ & \\
Sex Ratio $(\mathrm{L} / \mathrm{P})(\%)$ & 101,35 \\
$\%$ Penduduk Menurut Kelompok Umur \\
$0-14$ Thn & 23,86 \\
15-64 Thn & 69,10 \\
$>=65$ Thn & 7,04 \\
\hline
\end{tabular}

Sumber : BPS Kota Tomohon, 2013

\section{Jumlah Penduduk Kota Tomohon}

Penduduk adalah orang atau sekelompok orang yang tinggal disuatu tempat. Adapun yang dimaksud penduduk indonesia adalah orang-orang yang menetap di indonesia (Tabel 3).

Tabel 3. Jumlah Penduduk Kota Tomohon Tahun 2005-2014

\begin{tabular}{|c|c|c|c|c|}
\hline \multirow[t]{2}{*}{ Tahun } & \multirow{2}{*}{$\begin{array}{c}\text { Luas } \\
\text { Area } \\
\left(\mathbf{K m}^{2}\right)\end{array}$} & \multirow{2}{*}{$\begin{array}{c}\text { Jumlah } \\
\text { Penduduk } \\
\text { (Jiwa) }\end{array}$} & \multicolumn{2}{|c|}{$\begin{array}{c}\text { Pertumbuhan } \\
\text { Penduduk }\end{array}$} \\
\hline & & & Jiwa & $\begin{array}{c}\text { Persen } \\
(\%)\end{array}$ \\
\hline 2005 & 114,20 & 86.997 & - & - \\
\hline 2006 & 114,20 & 80.841 & 6156 & $-7,62$ \\
\hline 2007 & 114,20 & 81.842 & 1001 & 1,23 \\
\hline $2008 *$ & 114,20 & 82.684 & 842 & 1,02 \\
\hline $2009 *$ & 114,20 & 83.200 & 516 & 0,63 \\
\hline $2010^{*}$ & 114,20 & 83.718 & 518 & 0,62 \\
\hline 2011 & 147,21 & 91.553 & 7835 & 8,56 \\
\hline 2012 & 147,21 & 92.583 & 1030 & 1,12 \\
\hline 2013 & 147,21 & 93.857 & 1274 & 1,35 \\
\hline 2014 & 147,21 & 95.157 & 1300 & 1,37 \\
\hline
\end{tabular}

Berdasarkan proyeksi pada Tabel 3, jumlah penduduk Kota Tomohon yang ada di 5 kecamatan pada awal tahun 2005 sekitar 86.997 jiwa kemudian menurun ditahun 2006 menjadi 80.841 jiwa atau turun sekitar $-7,62 \%$. Penurunan yang terjadi ditahun 2006, diakibatkan oleh masalah kesejahteraan sosial seperti banyak masyarakat miskin di Kota Tomohon yang semakin tinggi yang mengakibatkan penduduk yang tidak mendapatkan pekerjaan yang ada di Kota
Tomohon banyak yang berpindah tempat tinggal ke daerah lain untuk mencari pekerjaan yang mempunyai pendapatan yang lebih tinggi dari Kota Tomohon.

Peningkatan jumlah penduduk Kota Tomohon terjadi pada tahun 2007, walaupun ditahun 2007-2010 masih bersifat angka proyeksi tetapi penduduk Kota Tomohon terus mengalami peningkatan. Pada tahun 2011 peningkatan jumlah penduduk Kota Tomohon meningkat sangat signifikan sekitar $8,56 \%$ atau sebesar 91.553 jiwa diikuti dengan pertambahan luas area Kota Tomohon dari 114,20 $\mathrm{Km}^{2}$ menjadi $147,21 \mathrm{~km}^{2}$. Jumlah penduduk Kota Tomohon terus meningkat sampai pada tahun 2014 penduduk Kota Tomohon berjumlah 95.157 jiwa.

\section{Angkatan Kerja di Kota Tomohon}

Angkatan kerja adalah bagian dari tenaga kerja yang sesungguhnya terlibat atau berusaha untuk terlibat dalam kegiatan yang produktif (Tabel 4).

\begin{tabular}{|c|c|c|c|}
\hline \multirow{4}{*}{ Tahun } & \multicolumn{2}{|c|}{ Angkatan Kerja } & \multirow{4}{*}{ Jumlah } \\
\hline & Parnah & Tidol & \\
\hline & & & \\
\hline & Bekerja & Pernah & \\
\hline 2009 & 2249 & $\frac{\text { Denerga }}{2.135}$ & 4.384 \\
\hline 2010 & 2.218 & 2.352 & 4.570 \\
\hline 2011 & 2.256 & 1.603 & 3.859 \\
\hline 2012 & 2.295 & 1.516 & 3.811 \\
\hline 2013 & 748 & 1.873 & 2.621 \\
\hline 2014 & & & \\
\hline
\end{tabular}

Sumber: BPS Kota Tomohon, diolah

Berdasarkan Tabel 4, tingkat partisipasi angkatan kerja mengalami penurunan seiring dengan menurunnya jumlah angkatan kerja pada tahun 2011 sampai tahun 2013 yang diakibatkan jumlah lapangan pekerjaan yang tidak sebanding dengan jumlah angkatan kerja sehingga jumlah penganguran meningkat yang mengakibatkan jumlah angkatan kerja menurun dibandingkan dengan tahun 2010 jumlah angkatan kerja meningkat dan kembali menurun ditahun 2011-2013. 


\section{Penggunaan Lahan Di Kota Tomohon}

Lahan mempunyai perananan sangat penting bagi kehidupan manusia, karena setiap pembangunan yang di lakukan membutukan lahan. Disini kita boleh melihat penggunaan lahan di Kota Tomohon, ada banyak penggunaan lahan di Kota Tomohon contohnya penggunaan lahan untuk pertanian, di sini lahan pertanian mencakup perkebunan, kehutanan, peternakan dan perikanan. dan disini penulis menggabungkan menjadi satu, begitu juga dengan yang lainnya seperti pendidikan,perkantoran tempat ibadah dan lainlain.

Tabel 5. Penggunaan Lahan Kota Tomohon 2014

\begin{tabular}{lcc}
\hline $\begin{array}{c}\text { Penggunaan } \\
\text { Lahan }\end{array}$ & Luas (Ha) & $\begin{array}{c}\text { Persentase } \\
(\mathbf{\%})\end{array}$ \\
\hline Pertanian & 1.089 & 69,58 \\
Pendidikan & 35,00 & 2,23 \\
Perkantoran & 30,00 & 1,91 \\
Tempat Ibadah & 29,00 & 1,85 \\
Bisnis & 12,00 & 0,76 \\
Fasilitas Umum & 87,00 & 5,55 \\
Instalasi & 5,00 & 0,31 \\
Industri & 4,00 & 0,25 \\
Pemukiman & 274,00 & 17,51 \\
\hline Sumber: BPN Kota Tomohon
\end{tabular}

Berdasarkan Tabel 5. Dapat di lihat penggunaan lahan yang paling dominan untuk sektor pertanian yakni $1.089 \mathrm{Ha}$ dengan persentase $69,58 \%$. Hal ini menunjukan bahwa sektor pertanian mendominasi penggunaan lahan dan sektor pertanian sebagai mata pencaharian sebagian besar masyarakat Kota Tomohon. Setelah sektor pertanian penggunaan lahan kedua terbesar adalah untuk pemukiman dengan pertumbuhan mencapai $1,37 \%$, ini berarti penggunaan lahan ini akan meningkat seiring dengan pertambahan penduduk. Dengan berkembangnya Kota Tomohon akan berimplikasi pada kebutuhan lahan baik untuk bisnis, tempat ibadah, fasilitas umum yang akan meningkat. Kemudian untuk penggunaan lahan ketiga terbesar adalah fasilitas umum seperti terminal lapangan dan lain-lain yang dari tahun ke tahun terus mengalami peningkatan. Setelah fasilitas umum pendidikan yang terbesar keempat, kemudian perkantoran di ikuti oleh tempat ibadah dan setelah itu menyusul lahan untuk bisnis instalasi dan industri.

\section{Luas Lahan Pertanian}

Dalam melakukan usaha di bidang Pertanian, Lahan merupakan salah satu faktor yang sangat penting untuk menghasilkan suatu produksi.

Tabel 6. Luas Lahan pertanian di Kota Tomohon Tahun 2008 - 2014

\begin{tabular}{|c|c|c|c|}
\hline Tahun & $\begin{array}{c}\text { Luas } \\
\text { Lahan } \\
\text { Perta- } \\
\text { nian } \\
\text { (Ha) }\end{array}$ & $\begin{array}{c}\text { Pertum- } \\
\text { buhan } \\
(\%)\end{array}$ & $\begin{array}{c}\text { Keterang- } \\
\text { an }\end{array}$ \\
\hline 2008 & $9.151,08$ & & \\
\hline 2009 & $\begin{array}{c}10.418,5 \\
1\end{array}$ & 13,85 & Bertambah \\
\hline 2010 & $\begin{array}{c}10.685,0 \\
8\end{array}$ & 2,55 & Bertambah \\
\hline 2011 & $\begin{array}{c}10.917,6 \\
5\end{array}$ & 2,17 & Bertambah \\
\hline 2012 & $\begin{array}{c}10.723,3 \\
5\end{array}$ & $-1,77$ & Berkurang \\
\hline 2013 & $\begin{array}{c}10.573,8 \\
6\end{array}$ & $-1,39$ & Berkurang \\
\hline 2014 & $\begin{array}{c}10.573,8 \\
6\end{array}$ & 0,01 & Berkurang \\
\hline
\end{tabular}

Sumber: BPS Kota Tomohon

Berdasarkan Tabel 6. Pertumbuhan luas lahan pertanian di Kota Tomohon pada tahun 2008-2009 sebesar 13.85\% yang di karenakan pelebaran lahan seperti kawasan hutan yang dulunya hutan di olah menjadi lahan pertanian. Di tahun 2009-2010 dan 2010-2011 luas lahan pertanian di Kota Tomohon kembali bertambah,pertumbuhannya masing-masing sebesar 2,55\% dan 2,17\%. Kemudian Pada tahun 2011-2014 luas lahan pertanian mulai menyusut yang di akibatkan banyaknya pembangunan yang di lakukan terutama untuk pemukiman perkantoran dan lain-lain.

\section{Produk Domestik Regional Bruto Kota Tomohon}

Produk Domestik Regional Bruto dapat didefinisikan sebagai jumlah nilai tambah yang dihasilkan oleh seluruh unit usaha dalam suatu wilayah, atau merupakan jumlah seluruh nilai 
barang dan jasa akhir yang dihasilkan oleh seluruh unit ekonomi disuatu wilayah.Batas wilayah perhitungan PDRB adalah daerah (perekonomian domestik) hal ini memungkinkan untuk mengukur sejauh mana kebijakan-kebijakan ekonomi yang diterapkan pemerintah mampu mendorong aktivitas perekonomian domestik. Untuk menghitung tingkat pertumbuhan di Kota Tomohon maka digunakan data PDRB atas dasar harga konstan, artinya pertumbuhan PDRB mencerminkan pertumbuhan output yang dihasilkan perekonomian dalam periode tertentu (Tabel 7).

Berdasarkan Tabel 7, 9 sektor lapangan usaha di Kota Tomohon yang ada dari tahun 2004 - 2008 menunjukan peningkatan yang baik dari tahun 2004 - tahun 2008. Terutama pada sektor bangunan / kontruksi menunjukkan angka yang paling tinggi. Sektor lapangan usaha di Kota Tomohon yang ada dari tahun 2009 - 2013 menunjukan peningkatan yang baik dari tahun 2009 - tahun 2013. Terutama pada sektor bangunan / kontruksi menunjukan angka yang paling tinggi pada tahun 2013 diantara sektor-sektor yang lain. Penyajian PDRB menurut lapangan usaha dapat memberikan gambaran mengenai peranan masing - masing sektor perekonomian dalam menciptakan nilai tambah disuatu daerah. Dalam Tabel 8 dapat dilihat kontribusi sektor pertanian terhadap perekonomian Kota Tomohon.

Tabel 7. Produk Domestik Regional Bruto Kota Tomohon ADHK 2000 Menurut Lapangan Usaha 2004-2013 (Juta Rupiah)

\begin{tabular}{|c|c|c|c|c|c|c|c|c|c|}
\hline \multirow[t]{2}{*}{ Tahun } & \multicolumn{9}{|c|}{ Lapangan Usaha } \\
\hline & 1 & 2 & 3 & 4 & 5 & 6 & 7 & 8 & 9 \\
\hline 2004 & $80.895,18$ & $35.821,65$ & $36.304,98$ & $4.522,41$ & $117.176,29$ & $67.608,29$ & $27.051,60$ & $12.472,33$ & $84.577,38$ \\
\hline 2005 & $84.263,01$ & $33.334,62$ & $37.205,34$ & $4.643,16$ & $124.398,29$ & $72.057,76$ & $28.672,95$ & $13.270,63$ & $87.929,, 25$ \\
\hline 2006 & $84.839,23$ & $39.137,67$ & $37.993,45$ & $4.430,36$ & $132.665,01$ & $76.127,65$ & $30.986,55$ & $14.081,03$ & $92.953,09$ \\
\hline 2007 & $87.988,85$ & $41.405,91$ & $38.947,86$ & $4.579,51$ & $141.566,83$ & $80.448,07$ & $32.945,44$ & $14.939,29$ & $98.220,79$ \\
\hline 2008 & $95.190,52$ & $45.765,39$ & $41.831,10$ & $4.969,99$ & $155.159,54$ & $88.236,67$ & $36.244,95$ & $16.218,10$ & $105.885,39$ \\
\hline 2009 & $97.338,30$ & $52.575,22$ & $44.383,65$ & $5.667,84$ & $162.451,22$ & $95.415,92$ & $39.005,26$ & $17.209,53$ & $111.354,99$ \\
\hline 2010 & $102.707,88$ & $54.192,60$ & $46.998,85$ & $5.993,09$ & $169.882,82$ & $104.718,38$ & $41.808,25$ & $18.401,61$ & $118.854,14$ \\
\hline 2011 & $104.331,76$ & $57.941,51$ & $49.993,65$ & $6.330,09$ & $181.922,68$ & $113.781,52$ & $43.882,31$ & $19.583,62$ & $129.207,04$ \\
\hline 2012 & $110.592,11$ & $67.731,40$ & $52.744,05$ & $6.754,58$ & $192.627,47$ & $119.156,81$ & $46.834,70$ & $20.573,14$ & $138.915,60$ \\
\hline 2013 & $116.793,69$ & $69.164,80$ & $55.348,66$ & $7.370,03$ & $208.203,86$ & $127.010,50$ & $50.921,43$ & $22.296,81$ & $151.196,92$ \\
\hline
\end{tabular}

Sumber : BPS Kota Tomohon

\section{Keterangan:}

(1) Pertanian, (2) Pertambangan \& Penggalian, (3) Industri Pengolahan, (4) Listrik, Gas dan Air Bersih, (5) Bangunan/Kontruksi, (6) Perdagangan, Hotel \& Restoran, (7) Pengangkutan \& Komunikasi, (8) Keuangan , Persewaaan \& Jasa Perusahaan, (9) Jasa-Jasa

Tabel 8. Kontribusi Sektoral Terhadap Perekonomian Kota Tomohon 2010-2014

\begin{tabular}{|c|c|c|c|c|c|c|}
\hline \multirow[t]{2}{*}{ No } & \multirow[t]{2}{*}{ Sektor } & \multicolumn{5}{|c|}{ Kontribusi $(\%)$} \\
\hline & & 2010 & 2011 & 2012 & 2013 & 2014 \\
\hline 1 & Pertanian & 14,56 & 14,49 & 14,34 & 14,11 & 13,85 \\
\hline 2 & Pertambangan dan Penggalian & 5,87 & 5,66 & 5,46 & 5,97 & 5,81 \\
\hline 3 & Industri Pengolahan & 7,25 & 7,25 & 7,04 & 6,78 & 6,43 \\
\hline 4 & Listrik, Gas dan Air Bersih & 0,89 & 0,87 & 0,85 & 0,86 & 0,87 \\
\hline 5 & Bangunan / Kontruksi & 28,03 & 27,44 & 27,69 & 27,67 & 28,04 \\
\hline 6 & Perdagangan, Hotel dan Restoran & 15,81 & 16,62 & 16,55 & 15,91 & 15,66 \\
\hline 7 & Angkutan dan Komunikasi & 6,97 & 7,06 & 7,00 & 7,17 & 7,36 \\
\hline 8 & Keuangan, Persewhan \& Jasa Pershn & 2,07 & 2,07 & 2,06 & 2,00 & 2,03 \\
\hline 9 & Jasa - Jasa & 18,55 & 18,54 & 19,02 & 19,54 & 19,96 \\
\hline
\end{tabular}

Sumber : BPS Kota Tomohon 2013 
Berdasarkan Tabel 8, dapat dilihat kontribusi sektor pertanian dalam pembentukan PDRB Kota Tomohon berada pada urutan ke empat dengan kontribusi 13,85 \% . Tahun 2014 ini kontribusi sektor pertanian turun di bandingkan tahun 2013 yang sebesar 14,11\%. Sektor pertanian di Kota Tomohon didominasi oleh sub sektor tanaman bahan makanan yang menyumbang 5,32 \% terhadap PDRB. Di tahun 2014 sektor ini tumbuh sebesar 5,61\%, lebih rendah di bandingkan tahun 2013 yang tumbuh sebesar $6 \%$. Di Kota Tomohon sektor pertambangan dan penggalian hanya di bentuk oleh sub sektor minyak dan gas bumi. Tahun 2014 sektor pertambangan dan penggalian ini mengalami pertumbuhan sebesar $2,12 \%$ sektor ini mengalami penurunan di bandingkan dengan tahun 2013 sebesar 16,90 \%. Sementara kontribusi sektor ini terhadap PDRB Kota Tomohon di tahun 2014 sebesar 5,81\%.

Pada sektor industri pengolahan, kontribusi yang dihasilkan didapatkan dari sub sektor industri tanpa minyak dan gas sebesar $6,43 \%$ pada tahun 2014. Sementara itu, pada tahun 2014 pertumbuhan sektor ini mengalami penurunan menjadi $4,94 \%$ di bandingkan tahun 2013 sebesar 5,50 \%. Dalam sektor listrik, gas dan air bersih hanya memberi kontribusi terkecil terhadap total PDRB Kota Tomohon, yakni hanya sebesar $0,87 \%$ dari total PDRB. Untuk Kota Tomohon, sektor ini dibentuk oleh dua sub sektor yaitu, sub sektor listrik dan sub sektor air bersih, sedangkan sub sektor gas kota tidak ada. Sebagai kota yang sedang membangun, sektor bangunan / Kontruksi Kota Tomohon cenderung mengalami peningkatan pertumbuhan dari tahun ke tahun. Pertumbuhan sektor ini pada tahun 2010 adalah sebesar $4,70 \%$, mengalami perlambatan pertumbuhan menjadi 4,57\%, pada tahun 2011, dan mengalami percepatan di tahun 2012 menjadi sebesar 7,09\%. Pada tahun 2012 sektor ini mengalami perlambatan lagi sebesar 5,88 \%, dan mengalami pertumbuhan di tahun 2014 menjadi 8,09 \%. Dilihat dari kontribusinya sektor bangunan / kontruksi memberikan kontribusi yang sangat besar bagi PDRB Kota Tomohon yaitu sebesar 28,04\% di taun 2014 .

Sektor perdagangan, hotel dan restoran yang ada di Kota Tomohon mengalami penurunan dari tahun ke tahun tetapi di tahun
2011 sektor ini mengalami peningkatan walaupun tidak terlalu signifikan. Sektor ini menyumbang kontribusi yang di berikan terhadap PDRB pada tahun 2014 adalah sebesar $15,66 \%$.

Pada tahun 2014 sektor angkutan dan komunikasi di Kota Tomohon meningkat di bandingkan tahun sebelumnya di mana pertumbuhannya hanya mencapai $6,73 \%$. Kontribusi sektor ini terhadap perekonomian Kota Tomohon di tahun 2014 adalah sebesar $7,36 \%$. Pada sektor bank, lembaga keungan, persewahan dan jasa perusahaan di Kota Tomohon memiliki 4 sub sektor yaitu sub sektor bank, sub sektor lembaga keuangan non bank, sub sektor persewahan dan sub sektor jasa perusahaan selama tahun 2014 sektor ini tumbuh sebesar 8,38 \% dengan kontribusi terhadap PDRB Kota Tomohon $2,03 \%$.

Sektor jasa yang ada di Kota Tomohon mempunyai sub sektor seperti jasa pemerintahan umum dan sub sektor jasa swasta. Selama tahun 2014 sektor ini memiliki peranan terbesar kedua terhadap total PDRB Kota Tomohon setelah sektor bangunan / kontruksi, yakni sebesar $19,96 \%$ dan mengalami pertumbuhan sektor 9,27\%. Pertumbuhan ini menurun di bandingkan tahun 2013 yang sebesar 9,60 \%. PDRB Kota Tomohon dari tahun ke tahun selama ini selalu mengalami peningkatan. Pertumbuhan PDRB atas harga konstan mengabarkan pertumbuhan secara rill perekonomian Kota Tomohon.

Struktur perekonomian Kota Tomohon masih di dominasi oleh sektor bangunan / kontruksi. Sebagai kota yang sementara membangun, perekonomian Kota Tomohon seharusnya dapat tumbuh lebih tinggi. Pertanian bunga yang menjadi ikon Kota Tomohon pertanian lain yang pada umumnya bisa lebih di tingkatkan dengan memacu penduduk untuk lebih meningkatakan sumber daya manusia dan menerapkan teknolgi yang tepat di bidang pertanian agar mampu menambah nilai tambah di sektor ini. 
Tabel 9. PDRB Subsektor Tanaman Pangan Kota Tomohon 2005 - 2014

\begin{tabular}{cccc}
\hline Tahun & $\begin{array}{c}\text { PDRB Sub Sektor } \\
\text { Pertanian } \\
\text { Tanaman Pangan } \\
\text { (Rp) }\end{array}$ & $\begin{array}{c}\text { Pertumbuhan } \\
\mathbf{\%}\end{array}$ & Keterangan \\
\hline 2005 & $30.838,44$ & 1,50 & Bertambah \\
2006 & $31.302,49$ & $-3,62$ & Berkurang \\
2007 & $30.760,87$ & 3,76 & Bertambah \\
2008 & $31.917,68$ & 10,23 & Bertambah \\
2009 & $35.185,20$ & 2,13 & Berkurang \\
2010 & $35.938,06$ & 4,92 & Bertambah \\
2011 & $37.706,93$ & 4,29 & Bertambah \\
$2012^{*}$ & $39.327,83$ & 5,05 & Bertambah \\
$2013^{* *}$ & $41.316,77$ & 5,73 & Bertambah \\
$2014 * * *$ & $43.686,02$ & & \\
\hline
\end{tabular}

Sumber : BPS Kota Tomohon

\section{Produk Domestik Regional Bruto Sektor Pertanian Kota Tomohon}

Produk Domestik Regional Bruto (PDRB) dapat didefinisikan sebagai jumlah nilai tambah yang dihasilkan oleh seluruh unit usaha dalam suatu wilayah, atau merupakan jumlah seluruh nilai barang dan jasa akhir yang dihasilkan oleh seluruh unit ekonomi disuatu wilayah.

Berdasarkan Tabel 9, Pertumbuhan Produk Domestik Regional Bruto Tanaman Pangan yang menyebabkan terjadinya peningkatan. Pertumbuhan Produk Domestik Regional Bruto pada tahun 2009-2010 mengalami penurunan sebesar 2.13\%. Dan di tahun 2010-2011 naik sebesar 4.92\%, tahun 2011-2012 Pertumbuhan Produk Domestik Regional Bruto naik sebesar $4.29 \%$, yang di sebabkan hampir semua tanaman pangan mengalami peningkatan seperti padi, jagung dan sayur-sayuran. tahun 20122013 naik sebesar 5.05\%, dan tahun 2013-2014 Pertumbuhan Produk domestik Regional Bruto naik mencapai $5.73 \%$.

Berdasarkan Tabel 10. Pertumbuhan Produk Domestik Regional Bruto Tanaman Perkebunan dari tahun 2005-2006 mengalami peningkatan sebesar $6.48 \%$, Pertumbuhan Produk Domestik tahun 2005-2006 naik sebesar 1.50\%, di karenakan jumlah produksi sayur-sayuran yang sangat besar yang membuat pertumbuhan PDRB meningkat. Di tahun 2006-2007 Pertumbuhan Produk Domestik Regional mengalami penurunan menjadi $-3.62 \%$ produksi padi yang sangat sedikit yang mengakibatkan penurunan pertumbuhan PDRB, kemudian di tahun 2007-2008 dan 2008-2009 masingmasing naik sebesar $3,76 \%$ dan $10.23 \%$ peningkatan produksi kentang dan wortel

Regional Bruto tanaman perkebunan terus mengalami peningkatan sampai tahun 2010. Di tahun 2006-2007 naik sebesar 4.90\%, tahun 2007-2008 sebesar 3.68\%, tahun 2008-2009 naik sebesar $6.38 \%$, di tahun 2009-2010 dan 2010-2011 masing-masing naik sebesar $1.07 \%$ dan 5.72\%. Di tahun 2011-2012 Pertumbuhan Produk Domestik Regional Bruto tanaman perkebunan mengalami penurunan sebesar $3.09 \%$ walaupun itu hanya angka sementara. Tahun 2012-2013 dan tahun 2013-2014 Pertumbuhan Produk Domestik Regional Bruto kembali naik walaupun itu hanya angka sangat sementara dan angka sangat- sangat sementara masing-masing sebesar $4.81 \%$ dan $5.57 \%$. 
Tabel 10. PDRB Subsektor Pertanian Tanaman Perkebunan 2005-2014

\begin{tabular}{cccc} 
Tahun & $\begin{array}{c}\text { PDRB Sub Sektor } \\
\text { Pertanian } \\
\text { Tanaman Perkebunan }\end{array}$ & $\begin{array}{c}\text { Pertumbuhan } \\
(\boldsymbol{\%})\end{array}$ & Keterangan \\
\hline 2005 & $30.017,55$ & 6,48 & Bertambah \\
2006 & $31.963,07$ & 4,90 & Bertambah \\
2007 & $33.531,24$ & 3,68 & Bertambah \\
2008 & $34.766,27$ & 6,38 & Bertambah \\
2009 & $36.985,85$ & 1,07 & Bertambah \\
2010 & $37.385,24$ & 5,72 & Bertambah \\
2011 & $39.524,20$ & $-3,09$ & Berkurang \\
$2012^{*}$ & $38.298,95$ & 4,81 & Bertambah \\
$2013 * *$ & $40.141,33$ & 5,57 & Bertambah \\
$2014 * * *$ & $42.377,61$ & &
\end{tabular}

Sumber : BPS Kota Tomohon

\begin{tabular}{cccc}
\hline \multicolumn{5}{c}{ Tabel 11. Hubungan Antara Luas Lahan Pertanian dengan PDRB Pertanian } \\
di Kota & Tomohon \\
\hline Tahun & Luas Lahan & $\begin{array}{c}\text { PDRB Sektor } \\
\text { Pertanian (Ha) }\end{array}$ & Keterengan \\
\hline 2005 & - & $80.895,18$ & \\
2006 & - & $84.263,01$ & PDRB Bertambah \\
2007 & - & $84.839,23$ & PDRB Bertambah \\
2008 & $9.151,08$ & $87.988,85$ & Luas Lahan Bertambah, PDRB Bertambah \\
2009 & $10.418,51$ & $95.190,52$ & Luas Lahan Bertambah, PDRB Bertambah \\
2010 & $10.685,08$ & $97.338,30$ & Luas Lahan Bertambah, PDRB Bertambah \\
2011 & $10.917,65$ & $102.707,88$ & Luas Lahan Bertambah, PDRB Bertambah \\
2012 & $10.723,35$ & $104.331,76$ & Luas Lahan Berkurang, PDRB Bertambah \\
2013 & $10.573,86$ & $110.592,11$ & Luas Lahan Berkurang, PDRB Bertambah \\
2014 & $10.573,86$ & $116.793,69$ & Luas Lahan Berkurang, PDRB Bertambah \\
\hline
\end{tabular}

Berdasarkan Tabel 11, Dapat di lihat Pada tahun 2004-2006 data luas lahan pertanian tidak tersedia, data Produk domestik regional bruto sektor pertanian pada tahun 2004 berjumlah 80.895,18 juta rupiah. Di tahun 2005 Produk domestik regional bruto sektor pertanian naik sebesar 84.263,01 juta rupiah, kemudian di tahun 2006 naik sebesar 84.839.23 juta rupiah. Pada tahun 2007 luas lahan pertanian di Kota Tomohon sebesar 9.151.08 ha, dan Produk domestik regional bruto sektor pertanian naik sebesar 87.988 .85 juta rupiah, Pada tahun 2008 luas lahan pertanian meningkat/naik dari 9.151.08 Ha menjadi 10.418.51 Ha, karena adanya pemekaran sehinga luas lahan pertanian mengalami peningkatan, kemudian produk domestik regional bruto sektor pertanian tahun 2008 naik sebesar 95.190.52 Ha, ada dua hal yang menyebabkan produk domestik regional bruto mengalami peningkatan yaitu tingginya/naiknya harga produksi Produk domestik regional bruto sektor pertanian dan jumlah produksi produk domestik regional bruto sektor pertanian yang tinggi, dan data membuktikan bahwa naiknya produk domestik regional bruto sektor pertanian di karenakan karena jumlah hasil produksi yang meningkat terutama pada subsektor perikanan. Kemudian pada tahun 2009-2010 luas lahan pertanian dan produk domestik regional bruto sektor pertanian masih sama, luas lahan pertanian 
tahun 2009 naik sebesar 10.685.08 ha, dan produk domestik regional bruto sektor pertanian naik sebesar 97.338.30 juta dan luas lahan pertanian tahun 2010 naik sebesar 10.917.65 Ha, dan produk domestik regional bruto sektor pertanian naik sebesar 102.707.88 juta. Kemudian pada tahun 2011 luas lahan pertanian mengalami penurunan dari 10.685.08 Ha menjadi 10.723.35 Ha ini di akibatkan karena banyak pembangunan yang di lakukan sehingga luas lahan mengalami penyusutan, mengingat Kota Tohohon adalah kota yang sedang membangun. Produk domestik regional bruto sektor pertanian pada tahun 2011 terus mengalami peningkatan walaupun luas lahan berkurang tetapi produksi subsektor yang di hasilkan meningkat terutama subsektor perikanan. Tahun 2012 luas lahan pertanian kembali mengalami penyusutan karena pembangunan yang di lakukan dari 10.723.35 menjadi 10.573.86, dan produk domestik regional bruto sektor pertanian tahun 2012 tetap mengalami peningkatan dan subsektor yang mendominasi peningkatan produk domestik regional bruto sektor pertanian adalah subsektor peternakan dan hasil-hasilnya. Pada tahun 2013 luas lahan pertanian masih sama dengan tahun sebelumnya sebesar $10.573 .86 \mathrm{Ha}$, produk domestik regional bruto sektor pertanian terus mengalami peningkatan dari 110.592 .11 juta menjadi 116.793.69 juta, dan subsektor yang berkontribusi besar terhadap produk domestik regional bruto sektor pertanian adalah subsektor perikanan.

Analisis korelasi adalah metode statistik yang digunakan untuk mengukur besarnya hubungan linear antara dua variabel atau lebih. Untuk melihat korelasi atau variabel luas lahan pertanian dan variabel PDRB Sektor Pertanian di gunakan rumus :

$\operatorname{Correl}(\mathrm{X}, \mathrm{Y})=\frac{\Sigma(x-x)(y-y)}{\sqrt{\Sigma(x-x)^{2} \Sigma(y-y)^{2}}}$

Dimana :

$\mathrm{Y}=$ Luas Lahan Pertanian (Ha)

$\mathrm{X}=\mathrm{PDRB}$ Sektor Pertanian

Adapun ukuran korelasi yang

digunakan terdapat pada Tabel 13.

Tabel 12. Analisis Korelasi

Nilai Korelasi Sampel Interpretasinya

$\begin{array}{cc}0.00-0.09 & \text { Hubungan korelasinya diabaikan } \\ 0.10-0.29 & \text { Hubungan korelasinya rendah } \\ 0.30-0.49 & \text { Hubungan korelasinya moderat } \\ 0.50-0.70 & \text { Hubungan korelsinya sedang } \\ >0.70 & \text { Hubungan korelasinya sangat kuat }\end{array}$

Sumber: Simbolon, 2009

Tabel 13. Ukuran Korelasi

\begin{tabular}{cccc}
\hline Tahun & Luas Lahan Pertanian & PDRB Sektor Pertanian & Analisis Korelasi \\
\hline 2008 & $9.151,08$ & $87.988,85$ & 0,62 \\
2009 & $10.418,51$ & $95.190,52$ & \\
2010 & $10.685,08$ & $97.338,30$ & \\
2011 & $10.917,65$ & $102.707,88$ & \\
2012 & $10.723,35$ & $104.331,76$ & \\
2013 & $10.573,86$ & $110.592,11$ & \\
2014 & $10.573,86$ & $116.793,69$ & \\
\hline
\end{tabular}


Hasil analisis korelasi antara luas lahan pertanian dengan produk domestik regional bruto sektor pertanian di Kota Tomohon adalah sebesar 0,62 dengan interpretasinya atau hubungan korelasinya sedang yang di karenakan adanya faktor lain yang mempengaruhi produk domestik regional bruto sektor pertanian Kota Tomohon.

\section{KESIMPULAN DAN SARAN}

\section{Kesimpulan}

Berdasarkan hasil penelitian yang di lakukan, yang menjadi kesimpulan:

1. Terdapat hubungan antara luas lahan pertanian dengan produk domestik regional bruto sektor pertanian, ketika luas lahan meningkat atau menurun produk domestik regional bruto tetap meningkat.

2. Hubungan antara luas lahan pertanian dengan produk domestik regional bruto sektor pertanian dikategorikan berkorelasi sedang dengan nilai korelasinya 0,62 .

\section{Saran}

Adapun saran dalam penelitian ini :

1. Perlu di lakukan penelitian lebih lanjut dengan memasukan variabel yang lebih banyak.

2. Dalam melakukan kebijakan penggunaan lahan pemerintah perlu memperhatikan sektor pertanian sebagai sektor yang dominan.

\section{Daftar Pustaka.}

Arsyad, S dan Rustiadi E. 2008. Penyelamatan Tanah, Air Dan Lingkungan. Bogor.

Badan Pusat Statistik. Provinsi Sulawesi Utara. 2014. Penduduk Sulawesi Utara Tahun 2008-2014. Manado.

Badan Pusat Statistik Kota Tomohon, 2014. Kota Tomohon Dalam Angka 2008- 2014. Tomohon.

Badan Pertanahan Nasional Kota Tomohon,2014. Luas Penggunaan Lahan. Tomohon.
Baja, 2014. Perencanaan Tata Guna Lahan Dan Pengembangan Wilayah. Yogyakarta.

Brinkman, A. R. dan A.J Smyth. 1973. Land Evaluation for Rural Purposes. ILRI Publ. No. 17 Wageningen.

Harjanto, Hadayat,W.,2003, Konsep Dasar Penilaian

Properti,BPFE, Yogyakarta.

Gujarati D, Porter D 2010. Dasar- dasar Ekometrika. Jakarta. Juhadi, 2007, Pola-Pola Pemanfaatan Lahan Dan Degradasi Lingkungan Pada Kawasan Perbukitan. Skripsi. FIS UNNES. Jakarta

Laoh, E. 2008. Buku Ajar Ekonomi Pembangunan, Fakultas Pertanian Universitas Sam Ratulangi, Manado. Manurung,Rahardja,P.,2008,

Pengantar Ilmu Ekonomi (Mikroekonomi \& Makroekonomi), Fakultas Ekonomi Universitas Indonesia, Jakarta.

Manuwoto, 1991. Dampak Perubahan Penggunaan Lahan. Lampung

Muchsin, Keoswahyono I., 2008, Aspek Kebijakan Hukum Penatagunaan Tanah Dan Penataan Ruang, Sinar Grafika, Jakarta.

Nugroho I, Dahuri R 2012. Pembangunan Wilayah : Perspektif Ekonomi Sosial Dan Lingkungan. LP3ES. Jakarta.

Sengka, C. A. 2015. Analisis Tenaga Kerja Sektoral Di Kota Tomohon. Skripsi Fakultas Pertanian Universitas Sam Ratulangi, Mando.

Simbolon, H. 2009. Statistika: Graha Ilmu. Jakarta

Sjafrizal, 2015. Perencanaan Pembangunan Daerah Dalam Era Otonomi. Jakarta.

Suhendra, E. S . 2004. Analisis Struktur Ekonomi Pertanian Indonesia, Model Input Output, Jurnal Ekonomi Dan Bisnis No 2, Jilid 9, Tahun 2004 Universitas Guna Darma Depok.

Sutarminingsih, 2003. Vertikultur Pola Bertanam Secara Vertikal. Yogyakarta.

Sutrisno, L. 2000. Menuju Masyarakat Partisipatitif, Edisi Kedua, Kanisius Jakarta 